\title{
Towards the third generation universities: The core innovative function approach
}

\author{
Ali Asghar Ghorbani ${ }^{1}$, Zohreh Sohrabi ${ }^{1 * \mathbb{D}}$, Shahram Yazdani ${ }^{2}$, Salimeh Khalili Azandehi ${ }^{3}$ \\ Received: 25 May 2019 \\ Published: 8 Mar 2021
}

\begin{abstract}
Background: Undoubtedly, economic and social value added depends on the functions of universities. Moving toward thirdgeneration universities (3rd GU) is an inevitable process. These universities need different functions than traditional ones; therefore, identifying and determining their functions is essential. The purpose of this study is to collect, match and explore the functions of universities in the transition to 3rd GU and ultimately offer a functional model of the 3rd GU for the use of professors, academics and policymakers in order to evaluate and promote universities.

Methods: A critical review method was adapted. Literature was included based on their relevant empirical data to research objectives and referral rates, and texts with more conceptual richness entered the study without time limitations.

Results: A total of 20 texts were included in the final analysis. While presenting the basic model, extracts the overarching concepts associated with the success of 3rd GU. These key concepts include the 7 core functions of innovative and entrepreneurial activities, supportive activities (financial and non-financial), entrepreneurial education ( curriculum and academic workforce empowerment), creation and provide applied knowledge, boundary-spanning function or communications and interactions with other elements of the national innovation system (state and industry), develop innovative and entrepreneurial culture and institutional governance and leadership in the direction of economic growth and development.

Conclusion: Using new functions at universities would be a move toward 3rd GU, economic growth and development in the country. So, these functions are a practically useful guide to policymakers to estimate the rate of success in each university and deliver the necessary suggestions to provide the mechanisms for the establishment of a successful university.
\end{abstract}

Keywords: Innovation Function, Transition, Third Generation University

Conflicts of Interest: None declared

Funding: Iran University of Medical Sciences (Code no. IR. IUMS. FMD.REC1396.9221486203).

*This work has been published under CC BY-NC-SA 1.0 license.

Copyright $\subseteq$ Iran University of Medical Sciences

Cite this article as: Ghorbani AA, Sohrabi Z, Yazdani Sh. Khalili Azandehi S. Towards the third generation universities: The core innovative function approach. Med J Islam Repub Iran. 2021 (8 Mar);35:32. https://doi.org/10.47176/mjiri.35.32

\section{Introduction}

Universities are changing, and the transition phase in a fundamental way. First-generation universities (medieval), tended to education. The transition to second-generation universities (the first transfer) is rooted in the social transi-

Corresponding author: Dr Zohreh Sohrabi, Sohrabi.z@iums.ac.ir

1. Center of Educational Research in Medical Sciences (CERMS), Department of Medical Education, School of Medicine, Iran University of Medical Sciences, Tehran, Iran

2. Shahid Beheshti University of Medical Sciences, School of Management and Medical Education, Tehran, Iran

3. Social Security Organization, Valiasr Regional Hospital, Education \& Research Unit, Ghaemshahr, Iran tion between the Renaissance and the Enlightenment. The purpose of these universit ies is to create knowledge and research. Although second-generation universities have their own quality and attraction, the constant struggle to

\section{$\uparrow$ What is "already known" in this topic:}

The current functions of universities (education and research) do not have much impact on the country's economic growth and development. Therefore, we need to redefine the functions for the economic and social value added in order to upgrade the universities. In this case, universities will move toward thirdgeneration universities.

\section{$\rightarrow$ What this article adds:}

This paper, for the first time, identifies the innovative functions of third-generation universities and provides guidance for the leadership and governance of universities in evaluating and promoting universities in order to achieve economic and social added value. 
get enough budgets and the limited role of universities in scientific research and education has led to the rethinking of the emergence of thinking such as the specialization of universities and the emergence of $3^{\text {rd }} \mathrm{GU}$ in the late nineteenth century. It means that universities should become centers for producing basic knowledge, and companies and institutions need to translate knowledge into practical solutions for the application of applied knowledge (1).

The concept of the $3^{\text {rd }}$ Generation University was introduced through Weissama in 2009 in link with the second scientific revolution. He believes that universities, given the increasing struggle for absorption investment, students and academics are changing as government demands for technology-led economic growth and economic and social development is now tied to the mission of universities (2).

In the second transition period from modern to postmodern in the late twentieth century and the emergence of $3^{\text {rd }} \mathrm{GU}$, universities are experiencing commercialization models and can be considered as tools for economic growth. Their goal is to generate knowledge and conduct research, and exploit applied knowledge. Their role is to create wealth, operate in a modern and interdisciplinary way, and educate professionals, scientists and entrepreneurs and have a global trend (1).

In the new approach to the role of universities, the $3^{\text {rd }}$ $\mathrm{GU}$ is defined as a center for the production, transfer, and implementation of innovation by maintaining the function of traditional universities. In fact, the approach of these universities is not only based on the organization of research but also on progress and development (3).

Therefore, given the fact that the emergence of the $3^{\text {rd }}$ GU is inevitable and these universities need different functions than the traditional universities, and on the other hand, the relevant literature and articles are less, providing the functions of the $3^{\text {rd }}$ GU seems a necessity. Finally, this study aims to provide a model of core innovation functions of the $3^{\text {rd }} \mathrm{GU}$ for the use of professors, academics and policy-makers in order to evaluate and promote universities. Obviously, applying these functions to universities will lead them to their new mission (economic and social development).

\section{Methods}

This paper undertakes the literature through a critical review. This was chosen because the dominant form of articles related to $3^{\text {rd }} \mathrm{GU}$ was mainly about the views, models, and patterns, and not intended to measure effectiveness; we also sought to identify the most meaningful concepts in the field of $3^{\text {rd }} \mathrm{GU}$ and present the model. A critical review approach is the widespread identification of texts, the critical evaluation of their quality, along with the degree of innovative analysis and synthesis, and, ultimately, elaborates and abstracts of a model or hypothesis (4).

\section{Search Strategy and Selection Criteria}

The search for literature included data that was prioritized based on their relevant empirical data to research objectives and referral rates, and texts with more conceptual richness, entered the study and were purposefully and comprehensively reviewed and extracted in a multi-stage process between English documents and articles without time limitations and by using relevant keywords in the PubMed, Embase, Google Scholar, Google, ERIC, Scopus, Elsevier, Web of Science, OVID, EBSCO, and Science Direct databases. These databases were chosen for their comprehensiveness and relevance to the review ob-

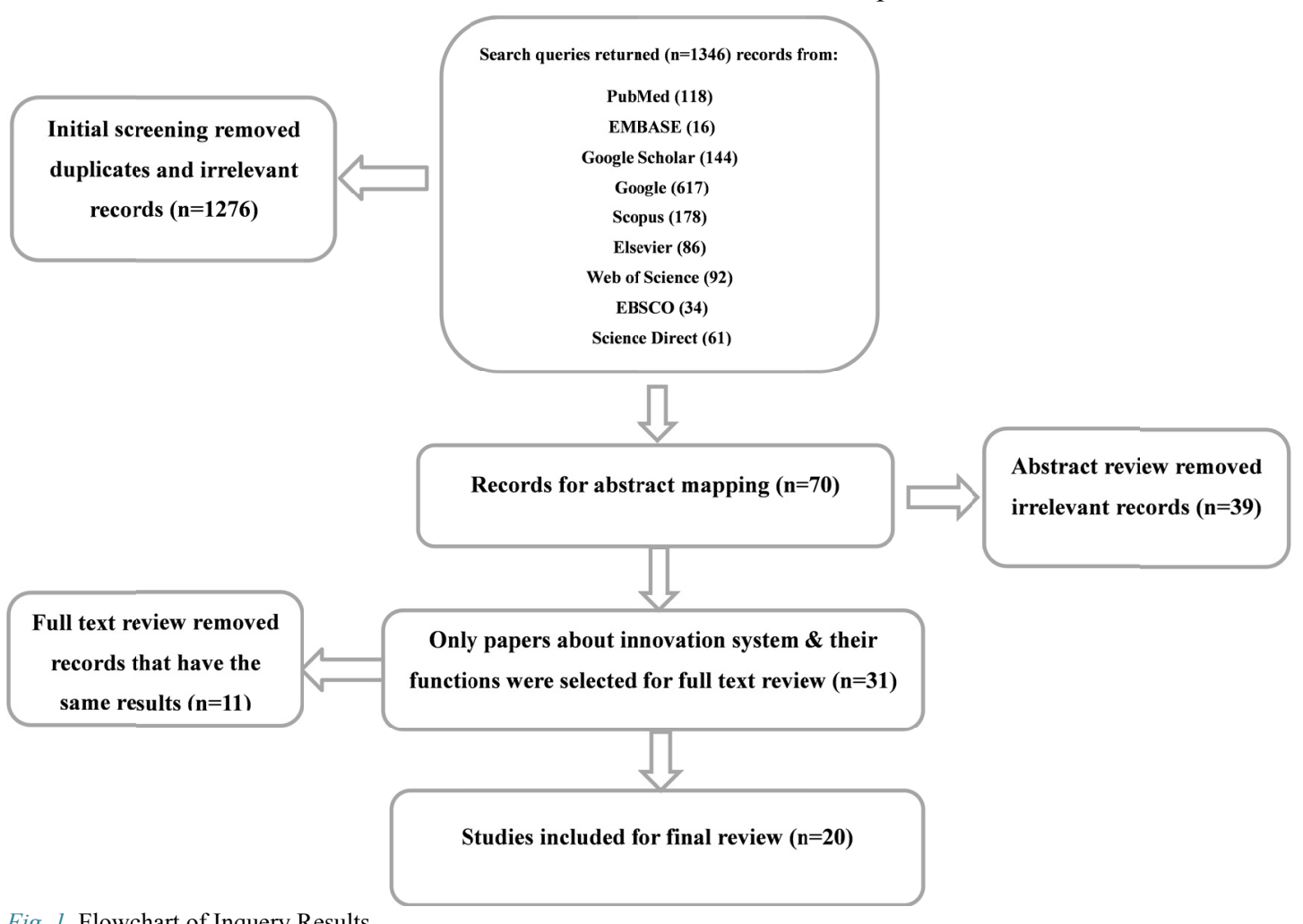

Fig. 1. Flowchart of Inquery Results 
jective. The texts that were not written in English and were not related to the functions of $3^{\text {rd }} \mathrm{GU}$ were excluded.

The search keywords included the " $3^{\text {rd }}$ Generation University, Functions of University, Entrepreneurial University, Medical Science Universities, Entrepreneurial Ecosystem, the Higher Education, Institutional Economics." Also, with regard to the scope of research, the following concepts are searched by OR and AND in combination with the main concepts.

"Knowledge development, Knowledge transfer, Knowledge translation, Transition, Technology transfer, Strategy"

In order to extract the final articles and based on the relationship between data and research objectives, the citation rate, and conceptual participation of the article in the synthesis and abstraction of the model, each article was examined individually by each member of the research team. Then, each of these articles was examined among the members of the research team with the same criteria.

Finally, the articles and texts that provided the definition or interpretation of the concepts, components, and functions of $3^{\text {rd }} \mathrm{GU}$ or provided evidence in connection with them, were chosen for studying the full text and the basis for the study (Fig. 1).

\section{Analysis}

First, each of the texts was critically studied and the key concepts related to the functions of the 3rd GU were extracted from each of the texts. Then, in order to reach a consensus, the concepts extracted by the members of the research team were examined. After finalizing the key concepts, the initial draft of the overarching concepts table was obtained, which after the process of iteration between the research team, the final concepts were classified. So, the overarching concepts and synthesizing in 10 categories based on the amount of conceptual contribution. Finally, the findings in these categories were abstracted our innovation functions model of $3^{\text {rd }} \mathrm{GU}$ according to original maturity.

\section{Results}

The result of the review and critique of related literature explored the core innovation functions of $3^{\text {rd }} \mathrm{GU}$. A summary of overarching concepts of functions of $3^{\text {rd }} \mathrm{GU}$ is presented in Table 1.

\section{Innovation activities}

Science, technology, and innovation reinforce competitiveness, productivity and job creation and act as key mechanisms for sustained growth in a knowledge-based economy. Knowledge valorization, knowledge transfer from research and development organizations ( $\mathrm{R} \& \mathrm{D})$ to other sectors that awaits socioeconomic values is mainly due to the fact that the industrial economy needs to change the own development paradigm from exploiting resourcesoriented to knowledge and innovation- oriented. There are three major interpretations of the concept of conversion of knowledge created to value by research and development: (i) knowledge valorization, (ii) knowledge com- mercialization, and (iii) knowledge investment (5).

\section{Entrepreneurial activities}

Entrepreneurship activity is important as one of the major goals of universities, and it is a new business accelerators a catalyst for widespread expansion and economic growth, it is a new business accelerator. According to Gianodis et al. 2016, the formation of start-ups is also one of the entrepreneurial activities of universities (6).

Compared to traditional academic environments, shifting to entrepreneurship needs the change of missions and functions within universities with their teaching and research as well as the development of entrepreneurial activities (7). Entrepreneurship is an important part of university strategy. To improve an entrepreneurial organization with an innovative culture, entrepreneurial activities should be developed in a strategy (8).

\section{Supportive activities}

The university's supporting activities refer to the two areas of financial support and non-financial support activities:

(A) non-financial support activities

The university's support for technology transfer and start-ups is one of the formal facilitating in the development and advancement of entrepreneurial universities. In a knowledge-based economy, universities are typically trying to support technology transfer and promote start-ups (9). Examples of this support are small business centers, research facilities, research teams or quasi-companies, communications agencies, technology transfer offices and incubators (10). Audretsch (2014) continues that the role of universities is beyond the production of technology transfer (patents, spin-offs and startups) (11), thus provides a special leadership to create thinking, activity, institutions and entrepreneurial capital (12).

The university should support the pre-launch phase of the start-up to commercial growth phase, including development and network coaching. Furthermore, universities need to connect their investors and their companies to the wider entrepreneurship ecosystem (8). Universities have built internal mechanisms to support academic entrepreneurship, namely the exploitation of the university's IP (13), the creation of spin-off and academic advisory activities, and, at university level, patent policies, spin-offs and advice is intended to control the business activities of academics (14).

\section{(B) financial support activities}

The venture capital and research grants are examples of university financial support activities. The university has a sustainable financial strategy to support entrepreneurship development, which includes funding or sufficient support for entrepreneurship activities as part of the (long-term) university's funding. Universities must invest in their entrepreneurial activities through their financial strategy. The university facilitates access to private financing for potential entrepreneurs (8). Venture capital has been created to provide the initial stages of commercialization of academic research $(15,16)$. 
Table 1. Overarching Concepts of Functions of $3^{\text {rd }} \mathrm{GU}$

\begin{tabular}{|c|c|c|c|c|c|c|c|c|c|c|}
\hline $\begin{array}{l}\text { Overarching } \\
\text { concepts }\end{array}$ & Kirby et al (2011) & OECD (2012) & $\begin{array}{c}\text { Guerrero \& Urbano } \\
\text { (2012) }\end{array}$ & $\begin{array}{l}\text { Paul Coyle et al. } \\
\text { (2013) }\end{array}$ & $\begin{array}{l}\text { Etzkowitz } \\
\text { (2013) }\end{array}$ & $\begin{array}{l}\text { Savetpanuvong \& } \\
\text { Pankasem (2014) }\end{array}$ & Baldini et al. (2015) & $\begin{array}{l}\text { Guerrero et al. } \\
\text { (2016) }\end{array}$ & $\begin{array}{l}\text { Gianiodis et al } \\
\text { (2016) }\end{array}$ & $\begin{array}{l}\text { Harrington \& } \\
\text { Walsh (2017) }\end{array}$ \\
\hline 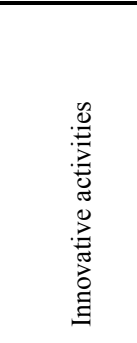 & $\begin{array}{c}\text { Develop innovative } \\
\text { activities }\end{array}$ & & $\begin{array}{l}\text { Commercializing } \\
\text { innovation from } \\
\text { university research }\end{array}$ & $\begin{array}{c}\text { Technological } \\
\text { innovation and } \\
\text { 'engines of growth' } \\
\text { Innovation in re- } \\
\text { search approaches, } \\
\text { achieving impact, } \\
\text { and finding a re- } \\
\text { source }\end{array}$ & $\begin{array}{l}\text { play a strategic } \\
\text { role in encourag- } \\
\text { ing innovation } \\
\text { Diffusing innova- } \\
\text { tion }\end{array}$ & $\begin{array}{c}\text { Transform from } \\
\text { bureaucracy and } \\
\text { corporatism into } \\
\text { multidisciplinary } \\
\\
\text { Transform its innova- } \\
\text { tion originator role to } \\
\text { innovation } \\
\text { diffusion role } \\
\text { convert its innovation } \\
\text { creator role to innova- } \\
\text { tion diffusion role }\end{array}$ & $\begin{array}{l}\text { support and diffuse } \\
\text { technology commer- } \\
\text { cialization activities in } \\
\text { academic institutions }\end{array}$ & $\begin{array}{c}\text { Development } \\
\text { and strengthen- } \\
\text { ing of national } \\
\text { innovation } \\
\text { ecosystems } \\
\text { Stimulate } \\
\text { innovation by } \\
\text { entrepreneurial } \\
\text { firms } \\
\text { as drivers of in- } \\
\text { novation }\end{array}$ & $\begin{array}{c}\text { Service innova- } \\
\text { tion and engage- } \\
\text { ment with organi- } \\
\text { zational learning } \\
\text { processes }\end{array}$ & $\begin{array}{c}\text { Enhancing } \\
\text { activities in a } \\
\text { regional innova- } \\
\text { tion system } \\
\text { Development of } \\
\text { innovation in } \\
\text { students }\end{array}$ \\
\hline 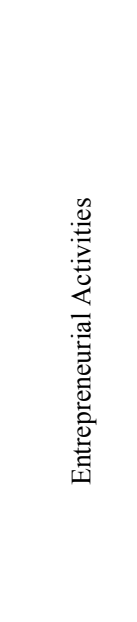 & $\begin{array}{l}\text { Development of } \\
\text { entrepreneurial } \\
\text { Activities } \\
\text { Commercialization } \\
\text { of their research } \\
\text { Entrepreneurship } \\
\text { role models } \\
\text { Contribution to } \\
\text { regional } \\
\text { development (jobs } \\
\text { created, } \\
\text { funding) } \\
\text { Minimal regulation } \\
\text { for new venture } \\
\text { creation } \\
\text { to encourage collec- } \\
\text { tive entrepreneurial } \\
\text { action at all levels. } \\
\text { Creation and } \\
\text { a spin-off of new } \\
\text { businesses }\end{array}$ & $\begin{array}{l}\text { Entrepreneurial } \\
\text { activities should be } \\
\text { established in the } \\
\text { strategy }\end{array}$ & $\begin{array}{l}\text { Employment crea- } \\
\text { tion } \\
\text { Entrepreneurial } \\
\text { universities play an } \\
\text { important role as } \\
\text { both } \\
\text { knowledge-producer } \\
\text { and a disseminating } \\
\text { institution } \\
\text { Encouraging the } \\
\text { formation of high- } \\
\text { technology firms } \\
\text { Minimal regulations } \\
\text { for new } \\
\text { venture creation }\end{array}$ & $\begin{array}{l}\text { universities for } \\
\text { employability and/or } \\
\text { employment, } \\
\text { universities for } \\
\text { useful knowledge, } \\
\text { universities for } \\
\text { enterprise, universi- } \\
\text { ties for social enter- } \\
\text { prise, and the 'busi- } \\
\text { ness engaged' } \\
\text { university. } \\
\text { Joint ventures with } \\
\text { business associa- } \\
\text { tions } \\
\text { and local authorities } \\
\text { in enterprise devel- } \\
\text { opment }\end{array}$ & $\begin{array}{l}\text { technology trans- } \\
\text { fer, } \\
\text { firm formation } \\
\text { and regional } \\
\text { development } \\
\text { commercializing } \\
\text { the intellectual } \\
\text { property } \\
\text { to organize a new } \\
\text { enterprise } \\
\text { Knowledge-based } \\
\text { regional devel- } \\
\text { opment strategy. }\end{array}$ & $\begin{array}{l}\text { Research and tech- } \\
\text { nology commerciali- } \\
\text { zation } \\
\text { produces entrepre- } \\
\text { neurs or new ventures } \\
\text { to the market } \\
\text { and society } \\
\text { foster } \\
\text { technology entrepre- } \\
\text { neurs with innovation } \\
\text { and societal } \\
\text { responsibility } \\
\text { foster the creation of } \\
\text { new ventures }\end{array}$ & $\begin{array}{c}\text { Successful commer- } \\
\text { cialization of universi- } \\
\text { ty research results } \\
\text { Involvement in aca- } \\
\text { demic entrepreneur- } \\
\text { ship has } \\
\text { different forms of pay- } \\
\text { offs for universities } \\
\\
\text { Development of } \\
\text { academic start-ups } \\
\text { The creation of aca- } \\
\text { demic spin-offs }\end{array}$ & $\begin{array}{l}\text { Growth through } \\
\text { innovation and } \\
\text { venturing } \\
\text { activities } \\
\text { Creation of } \\
\text { spin-offs }\end{array}$ & $\begin{array}{c}\begin{array}{c}\text { commercialization } \\
\text { of new technolo- } \\
\text { gies and business } \\
\text { communities }\end{array} \\
\text { Entrepreneurial } \\
\text { activity } \\
\text { The formation of } \\
\text { startups }\end{array}$ & \\
\hline
\end{tabular}


Table 1. Ctd

\begin{tabular}{|c|c|c|c|c|c|c|c|c|c|c|c|}
\hline & 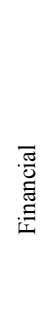 & Seed funding & $\begin{array}{l}\text { Generate revenues for } \\
\text { the institution from } \\
\text { spin-off activities; } \\
\text { Diversify funding } \\
\text { sources and reduce } \\
\text { their dependency on } \\
\text { state/public funding }\end{array}$ & $\begin{array}{l}\text { Availability of venture } \\
\text { capital } \\
\text { A diversified funding } \\
\text { base }\end{array}$ & $\begin{array}{l}\text { Broadening revenue } \\
\text { flows }\end{array}$ & $\begin{array}{l}\text { The venture-capital } \\
\text { model invented to } \\
\text { fund the early stages } \\
\text { of university re- } \\
\text { search commerciali- } \\
\text { zation }\end{array}$ & $\begin{array}{c}\text { Financing or adequate } \\
\text { support of entrepreneuri- } \\
\text { al activities }\end{array}$ & $\begin{array}{c}\text { creating } \\
\text { new mechanisms for } \\
\text { funding research activi- } \\
\text { ties }\end{array}$ & $\begin{array}{l}\text { access to private/ } \\
\text { public sources of } \\
\text { funding }\end{array}$ & & \\
\hline 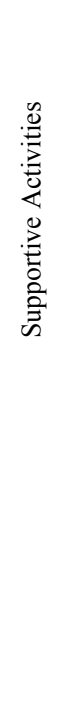 & 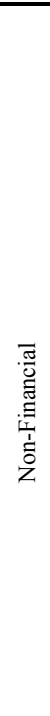 & $\begin{array}{l}\text { to support technology } \\
\text { transfer and } \\
\text { promote start-ups } \\
\text { An effective policy } \\
\text { concerning } \\
\text { intellectual-property to } \\
\text { promote technology } \\
\text { transfer }\end{array}$ & $\begin{array}{l}\text { Support business start- } \\
\text { ups; } \\
\text { provides access to } \\
\text { business incubation } \\
\text { facilities }\end{array}$ & $\begin{array}{l}\text { Support for technology } \\
\text { transfer } \\
\text { Support for start-ups } \\
\text { Science park } \\
\text { Encouragement and } \\
\text { support } \\
\text { Policies and technology }\end{array}$ & $\begin{array}{l}\text { technology transfer } \\
\text { offices, incubators and } \\
\text { science parks } \\
\text { Incubator and technol- } \\
\text { ogy park activity; } \\
\text { provide a platform for } \\
\text { wider exploration of } \\
\text { the university's entre- } \\
\text { preneurial potential }\end{array}$ & $\begin{array}{c}\text { Administrative } \\
\text { mechanisms such as } \\
\text { licensing offices and } \\
\text { incubator facilities }\end{array}$ & $\begin{array}{c}\text { Provides support for } \\
\text { individuals and groups to } \\
\text { move from entrepreneur- } \\
\text { ial ideas to action } \\
\text { should make mentoring } \\
\text { services available to both } \\
\text { student and graduate } \\
\text { entrepreneurs }\end{array}$ & $\begin{array}{l}\text { Development of universi- } \\
\text { ty patents } \\
\text { Licensing } \\
\text { Creation of Technology } \\
\text { Transfer Offices (TTOs), } \\
\text { The exploitation of } \\
\text { university-owned IP, }\end{array}$ & $\begin{array}{c}\text { technology } \\
\text { transfers, science } \\
\text { parks, incubators } \\
\text { Development of } \\
\text { spin-off firms, } \\
\text { patents, licenses }\end{array}$ & $\begin{array}{c}\text { based on their } \\
\text { institution's IP } \\
\text { Creation of } \\
\text { research parks } \\
\text { and business } \\
\text { incubators } \\
\text { entrepreneurial } \\
\text { activity as a } \\
\text { significant } \\
\text { source for } \\
\text { stakeholder sup- } \\
\text { port }\end{array}$ & $\begin{array}{c}\text { To increased start- } \\
\text { up activity at } \\
\text { universities }\end{array}$ \\
\hline
\end{tabular}




\begin{tabular}{|c|c|c|c|c|c|c|c|c|c|c|}
\hline 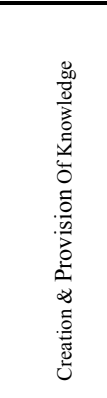 & $\begin{array}{l}\text { Knowledge transfer } \\
\text { (patents, } \\
\text { licenses, contracts) } \\
\text { Development of } \\
\text { knowledge-based } \\
\text { economies because they } \\
\text { generate, apply, and } \\
\text { disseminate knowledge }\end{array}$ & $\begin{array}{l}\text { Mechanisms in place for } \\
\text { exploiting internal } \\
\text { knowledge } \\
\text { To collaboration and } \\
\text { knowledge exchange } \\
\text { with industry, society, } \\
\text { and the public sector. } \\
\text { Support knowledge } \\
\text { exchange mechanisms } \\
\text { and collaboration with } \\
\text { the external environment }\end{array}$ & $\begin{array}{l}\text { Capitalization of } \\
\text { knowledge } \\
\text { Knowledge transfer } \\
\text { (patents, licenses, spin- } \\
\text { offs) } \\
\text { Exploitation of } \\
\text { knowledge }\end{array}$ & $\begin{array}{l}\text { Creating useful } \\
\text { knowledge } \\
\text { Strengthening of the } \\
\text { university's } \\
\text { capacity for knowledge } \\
\text { exchange } \\
\text { Research, knowledge } \\
\text { transfer, and exchange } \\
\text { Improving knowledge } \\
\text { exchange processes }\end{array}$ & $\begin{array}{l}\text { An institution in } \\
\text { which knowledge is } \\
\text { also created and put } \\
\text { to use. } \\
\text { Dissemination of } \\
\text { available knowledge } \\
\text { to include methodol- } \\
\text { ogies that retrieve } \\
\text { lost knowledge }\end{array}$ & $\begin{array}{l}\text { Knowledge management } \\
\text { Sharing knowledge over } \\
\text { the network } \\
\text { Exchange knowledge } \\
\text { anytime anyplace on any } \\
\text { device } \\
\text { Product multidisciplinary } \\
\text { knowledge }\end{array}$ & $\begin{array}{l}\text { Creation of academic } \\
\text { knowledge } \\
\text { Entrepreneurial knowledge } \\
\text { exchange activities within } \\
\text { the higher education sector }\end{array}$ & $\begin{array}{l}\text { Provider of } \\
\text { knowledge (tech- } \\
\text { nology) } \\
\text { Generation of } \\
\text { knowledge (a } \\
\text { traditional func- } \\
\text { tion) Knowledge } \\
\text { transfer to the } \\
\text { business (a new } \\
\text { function) } \\
\text { Intersection of } \\
\text { education, re-- } \\
\text { search, and transfer } \\
\text { of knowledge }\end{array}$ & $\begin{array}{l}\text { Knowledge and } \\
\text { technology } \\
\text { integration are } \\
\text { essential for the } \\
\text { commercializa- } \\
\text { tion of university } \\
\text { IP }\end{array}$ & $\begin{array}{l}\text { Knowledge-based } \\
\text { industries } \\
\text { Knowledge transfer } \\
\text { to industry } \\
\text { Contributing to } \\
\text { knowledge genera- } \\
\text { tion }\end{array}$ \\
\hline 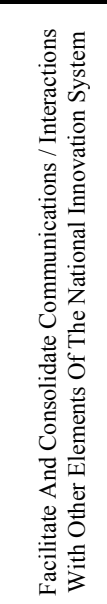 & 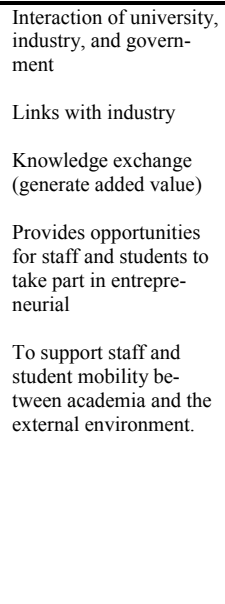 & $\begin{array}{l}\text { Support and drive } \\
\text { regional, social and } \\
\text { community development } \\
\text { Committed to collabora- } \\
\text { tion and knowledge } \\
\text { exchange with industry, } \\
\text { society and the public } \\
\text { sector } \\
\text { (support mechanisms for } \\
\text { coordinating these } \\
\text { relationships) } \\
\\
\text { Has strong links with } \\
\text { incubators, science } \\
\text { parks and other external } \\
\text { initiatives, creating } \\
\text { opportunities for dynam- } \\
\text { ic }\end{array}$ & $\begin{array}{l}\text { Involved in partnerships, } \\
\text { networks and other } \\
\text { relationships } \\
\text { with public and private } \\
\text { organizations } \\
\text { An umbrella for interac- } \\
\text { tion, collaboration, } \\
\text { co-operation and among } \\
\text { the core elements of a } \\
\text { national innovation } \\
\text { system } \\
\\
\text { Strong collaborative } \\
\text { agreements between } \\
\text { university and industry }\end{array}$ & $\begin{array}{l}\text { The creation of active } \\
\text { partnerships with other } \\
\text { universities, national } \\
\text { and international, with } \\
\text { local government } \\
\text { and development } \\
\text { agencies, with NGOs } \\
\text { Active involvement with } \\
\text { alumni groups } \\
\begin{array}{l}\text { Establishing close links } \\
\text { with the businesses and } \\
\text { communities }\end{array}\end{array}$ & $\begin{array}{l}\text { Interactions with } \\
\text { venture capitalists } \\
\text { and business } \\
\text { Interacts closely with } \\
\text { industry and govern- } \\
\text { ment } \\
\text { Academic advances } \\
\text { infuse new technolo- } \\
\text { gies into existing } \\
\text { industries } \\
\text { An entrepreneurial } \\
\text { university interacting } \\
\text { with industry and } \\
\text { government }\end{array}$ & $\begin{array}{l}\text { The interaction of } \\
\text { the university with the } \\
\text { environment, the "struc- } \\
\text { tural } \\
\text { coupling" between } \\
\text { university and region } \\
\text { The Triple Helix model is } \\
\text { the framework where } \\
\text { university, industry and } \\
\text { government interacting } \\
\text { dynamically to create } \\
\text { innovation for a } \\
\text { knowledge-based society. } \\
\text { Explore opportunity via } \\
\text { government and industrial } \\
\text { connection. }\end{array}$ & $\begin{array}{l}\text { Industry-university } \\
\text { collaborations } \\
\text { Interaction with the } \\
\text { industrial world }\end{array}$ & $\begin{array}{l}\text { Build- } \\
\text { ing/supporting } \\
\text { inter-relationships/ } \\
\text { linkages among } \\
\text { entrepreneurs, } \\
\text { venture capitalists, } \\
\text { business incuba- } \\
\text { tors, and other } \\
\text { actors } \\
\text { Industry-university } \\
\text { relations focusing } \\
\text { on the commercial- } \\
\text { ization }\end{array}$ & $\begin{array}{l}\text { Interactions } \\
\text { among individu- } \\
\text { als/ organiza- } \\
\text { tions, as well as, } \\
\text { organiza- } \\
\text { tions/contexts }\end{array}$ & $\begin{array}{l}\text { University-industry } \\
\text { relations } \\
\text { Research centers } \\
\text { can also play a role } \\
\text { in connecting } \\
\text { with industry and } \\
\text { developing depth in } \\
\text { these interactions } \\
\text {.Faculty should be } \\
\text { given the freedom } \\
\text { to pursue links with } \\
\text { industry }\end{array}$ \\
\hline
\end{tabular}

$6 \quad$ http://mjiri.iums.ac.ir 


\begin{tabular}{|c|c|c|c|c|c|c|c|c|c|c|c|}
\hline \multirow{2}{*}{ 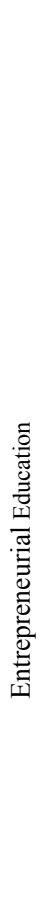 } & 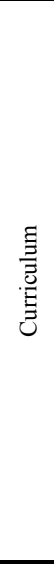 & 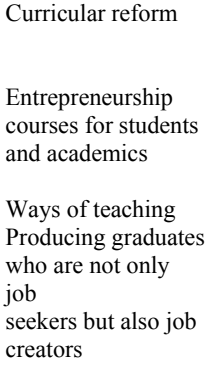 & $\begin{array}{l}\text { Research results are } \\
\text { integrated into } \\
\text { entrepreneurship } \\
\text { education and } \\
\text { training } \\
\text { (curriculum up-to- } \\
\text { date) } \\
\text { Promoting diversity } \\
\text { and innovation in } \\
\text { teaching and learn- } \\
\text { ing. } \\
\text { Entrepreneurial } \\
\text { behavior is encour- } \\
\text { aged and supported } \\
\text { throughout teaching } \\
\text { and in extracurricu- } \\
\text { lar activities }\end{array}$ & $\begin{array}{l}\text { Entrepreneurship } \\
\text { courses for students } \\
\text { and academics } \\
\text { Entrepreneurial } \\
\text { teaching methodol- } \\
\text { ogies }\end{array}$ & $\begin{array}{l}\text { 'Employability' is } \\
\text { being embedded } \\
\text { contextually in the } \\
\text { curriculum } \\
\text { Wider opportunities } \\
\text { for student experi- } \\
\text { ential }\end{array}$ & $\begin{array}{l}\text { Established } \\
\text { training programs } \\
\text { in entrepreneur- } \\
\text { ship designed to } \\
\text { create firms } \\
\text { To encourage } \\
\text { student entrepre- } \\
\text { neurs }\end{array}$ & $\begin{array}{l}\text { Recognize business } \\
\text { opportunities and } \\
\text { transform the ideas } \\
\text { to products through } \\
\text { action-oriented and } \\
\text { research integrated } \\
\text { curriculum }\end{array}$ & $\begin{array}{l}\text { Willingness to change } \\
\text { and } \\
\text { multidisciplinary } \\
\text { training }\end{array}$ & $\begin{array}{l}\text { The relevance } \\
\text { of entrepreneur- } \\
\text { ial education, } \\
\text { opportunity } \\
\text { recognitions } \\
\text { and intention, }\end{array}$ & $\begin{array}{l}\text { Validates entre- } \\
\text { preneurship } \\
\text { learning out- } \\
\text { comes }\end{array}$ & $\begin{array}{l}\text { Entrepreneurship } \\
\text { Education at } \\
\text { Universities } \\
\\
\text { Support entre- } \\
\text { preneurship and } \\
\text { entrepreneurship } \\
\text { education. } \\
\text { Entrepreneurship } \\
\text { teaching meth- } \\
\text { odologies, } \\
\text { through both } \\
\text { curricular and } \\
\text { extra-curricular } \\
\text { activities to } \\
\text { engage in entre- } \\
\text { preneurial and } \\
\text { creative activi- } \\
\text { ties }\end{array}$ \\
\hline & 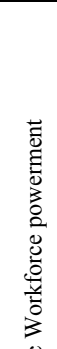 & $\begin{array}{l}\text { Recruit graduate } \\
\text { students interna- } \\
\text { tionally } \\
\text { Greater faculty } \\
\text { responsibility for } \\
\text { accessing external } \\
\text { sources of funding }\end{array}$ & $\begin{array}{l}\text { Stimulates and } \\
\text { supports the devel- } \\
\text { opment of entrepre- } \\
\text { neurial mindsets } \\
\text { and skills. } \\
\text { Generating entre- } \\
\text { preneurial compe- } \\
\text { tencies and skills; } \\
\text { Provides opportuni- } \\
\text { ties to experience } \\
\text { entrepreneurship. }\end{array}$ & $\begin{array}{l}\text { To develop both } \\
\text { creative and critical } \\
\text { thinking } \\
\text { Provides a } \\
\text { workforce and value } \\
\text { added with the } \\
\text { creation or trans- } \\
\text { formation of } \\
\text { knowledge }\end{array}$ & $\begin{array}{l}\text { learning experienc- } \\
\text { es alongside entre- } \\
\text { preneurial and } \\
\text { enterprise skills } \\
\text { Formal teaching and } \\
\text { learning strategies; } \\
\text { staff development } \\
\text { programs; and } \\
\text { student-led initia- } \\
\text { tives }\end{array}$ & $\begin{array}{l}\text { Encourage their } \\
\text { staffs to the } \\
\text { formation of a } \\
\text { firm. }\end{array}$ & $\begin{array}{l}\text { All staffs to be entre- } \\
\text { preneurial and build } \\
\text { teacher as a } \\
\text { business mentor or } \\
\text { industry consultants }\end{array}$ & $\begin{array}{l}\text { Entrepreneurship } \\
\text { education }\end{array}$ & $\begin{array}{l}\text { Strong contri- } \\
\text { butions proving } \\
\text { talent human } \\
\text { capital (entre- } \\
\text { preneurs, entre- } \\
\text { preneurs, em- } \\
\text { ployees) } \\
\text { Talented human } \\
\text { capital and a } \\
\text { qualified work- } \\
\text { force }\end{array}$ & $\begin{array}{l}\text { Invests in staff } \\
\text { development }\end{array}$ & $\begin{array}{l}\text { Successfully } \\
\text { producing grad- } \\
\text { uates with } \\
\text { entrepreneurial } \\
\text { mindsets }\end{array}$ \\
\hline
\end{tabular}




\begin{tabular}{|c|c|c|c|c|c|c|c|c|c|c|}
\hline 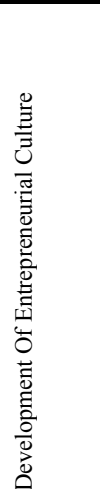 & $\begin{array}{l}\text { Development and } \\
\text { understanding an } \\
\text { entrepreneurial } \\
\text { culture } \\
\text { Favorable staff and } \\
\text { student attitudes } \\
\text { toward entrepreneur- } \\
\text { ship } \\
\text { Adequate cultural } \\
\text { values } \\
\text { Favorable attitudes } \\
\text { of students } \\
\text { and faculty toward } \\
\text { entrepreneurship }\end{array}$ & $\begin{array}{l}\text { Building an entre- } \\
\text { preneurial culture } \\
\text { within the staff body } \\
\text { Raises awareness of } \\
\text { the value/importance } \\
\text { of developing entre- } \\
\text { preneurial abilities } \\
\text { amongst staff and } \\
\text { students. } \\
\text { Build and foster an } \\
\text { entrepreneurial } \\
\text { culture }\end{array}$ & $\begin{array}{l}\text { Promote an entre- } \\
\text { preneurial } \\
\text { culture } \\
\text { Favorable student \& } \\
\text { staff attitudes to- } \\
\text { wards } \\
\text { entrepreneurship } \\
\\
\text { The entrepreneurial } \\
\text { attitudes of academ- } \\
\text { ics, managers, re- } \\
\text { searchers, staff } \\
\text { and students }\end{array}$ & $\begin{array}{l}\text { Development of the } \\
\text { 'enterprising person } \\
\text { and entrepreneurial } \\
\text { mindset' } \\
\text { A Strategy for Busi- } \\
\text { ness Engagement- } \\
\text { developing an Entre- } \\
\text { preneurial Culture } \\
\text { fostering a more } \\
\text { entrepreneurial } \\
\text { mindset in the organ- } \\
\text { izations }\end{array}$ & $\begin{array}{l}\text { Importance of } \\
\text { entrepreneurial } \\
\text { culture and behav- } \\
\text { ior will eventually } \\
\text { change the } \\
\text { core structures of } \\
\text { the university }\end{array}$ & $\begin{array}{l}\text { Promotion of entre- } \\
\text { preneurial } \\
\text { culture }\end{array}$ & $\begin{array}{l}\text { Increasing the oppor- } \\
\text { tunities to attract smart } \\
\text { people interested in the } \\
\text { commercialization of } \\
\text { their research results }\end{array}$ & $\begin{array}{l}\text { Supporting the } \\
\text { entrepreneurial } \\
\text { culture (values } \\
\text { and attitudes } \\
\text { toward educa- } \\
\text { tional programs) } \\
\text { The entrepre- } \\
\text { neuril culture at } \\
\text { institutions } \\
\text { was more holis- } \\
\text { tically }\end{array}$ & & $\begin{array}{l}\text { Development of } \\
\text { an entrepreneuri- } \\
\text { al culture } \\
\\
\text { Favorable atti- } \\
\text { tude by staff } \\
\text { toward entrepre- } \\
\text { neurship was } \\
\text { identified as the } \\
\text { most important } \\
\text { facilitator } \\
\text { Developing an } \\
\text { entrepreneurial } \\
\text { mindset }\end{array}$ \\
\hline 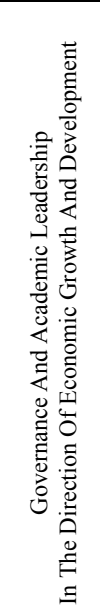 & $\begin{array}{l}\text { Have a new manage- } \\
\text { rial ethos in govern- } \\
\text { ance, leadership, and } \\
\text { planning } \\
\text { University } \\
\text { leaders should be } \\
\text { skilled at identifying } \\
\text { business opportuni- } \\
\text { ties } \\
\text { that arise from the } \\
\text { dynamic interaction } \\
\text { of the } \\
\text { organization and its } \\
\text { stakeholders } \\
\text { Appropriate reward } \\
\text { system }\end{array}$ & $\begin{array}{l}\text { Generating entrepre- } \\
\text { neurial motivation, } \\
\text { cognition, and atti- } \\
\text { tudes; } \\
\text { Gives status and } \\
\text { recognition to other } \\
\text { stakeholders } \\
\\
\text { Understand the value } \\
\text { of multiple stake- } \\
\text { holder engagement } \\
\text { to support entrepre- } \\
\text { neurship } \\
\text { Assesses the impact } \\
\text { of its entrepreneurial } \\
\text { strategy and the } \\
\text { strategy is respon- } \\
\text { sive to change }\end{array}$ & $\begin{array}{l}\text { Management, gov- } \\
\text { ernance and leader- } \\
\text { ship } \\
\text { Entrepreneurial } \\
\text { organizational and } \\
\text { governance struc- } \\
\text { ture, } \\
\text { Appropriate reward } \\
\text { systems } \\
\text { Entrepreneurship } \\
\text { role models }\end{array}$ & $\begin{array}{l}\text { Governance, strate- } \\
\text { gy, organization } \\
\text { design and leader- } \\
\text { ship at all levels } \\
\text { The entrepreneurial } \\
\text { leader is a role } \\
\text { model for enterpris- } \\
\text { ing behavior } \\
\text { Style of this trans- } \\
\text { formational leader- } \\
\text { ship model }\end{array}$ & $\begin{array}{l}\text { Assesses the level } \\
\text { of engagement in } \\
\text { entrepreneurial } \\
\text { teaching and } \\
\text { learning across the } \\
\text { institution } \\
\text { assesses the im- } \\
\text { pact of entrepre- } \\
\text { neurship teaching } \\
\text { and learning }\end{array}$ & $\begin{array}{l}\text { Management with } \\
\text { entrepreneurial style } \\
\text { to cultivate leader- } \\
\text { ship, initiative, dy- } \\
\text { namic founding team } \\
\text { (Resource-based } \\
\text { View) } \\
\text { Collaborative leader- } \\
\text { ship }\end{array}$ & $\begin{array}{l}\text { Be responsive to the } \\
\text { interests of a variety of } \\
\text { external stakeholders } \\
\text { Clear rules on intellec- } \\
\text { tual property owner- } \\
\text { ship }\end{array}$ & $\begin{array}{l}\text { Contribute and } \\
\text { provide leader- } \\
\text { ship for creating } \\
\text { entrepreneurial } \\
\text { thinking, ac- } \\
\text { tions, institu- } \\
\text { tions and entre- } \\
\text { preneurial } \\
\text { capital } \\
\text { Adopts an } \\
\text { entrepreneurial } \\
\text { management } \\
\text { style } \\
\text { To manage the } \\
\text { innova- } \\
\text { tion/entrepreneu } \\
\text { rship functions }\end{array}$ & $\begin{array}{l}\text { Provide effec- } \\
\text { tive incentive } \\
\text { systems for } \\
\text { scientists }\end{array}$ & $\begin{array}{l}\text { Involve man- } \\
\text { agement in } \\
\text { rewarding entre- } \\
\text { preneurial activi- } \\
\text { ty and encourag- } \\
\text { ing staff } \\
\text { Entrepreneurial } \\
\text { organization and } \\
\text { entrepreneurial } \\
\text { leadership } \\
\\
\text { Entrepreneurship } \\
\text { role models, and } \\
\text { reward system }\end{array}$ \\
\hline
\end{tabular}

$8 \quad$ http://mjiri.iums.ac.ir

\footnotetext{
Med J Islam Repub Iran. 2021 (8 Mar); 35:32.
} 


\begin{tabular}{|c|c|c|c|c|c|c|c|c|c|c|}
\hline 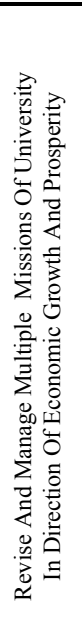 & $\begin{array}{l}\text { Their traditional } \\
\text { missions of teach- } \\
\text { ing and research, } \\
\text { add the generation } \\
\text { of social and eco- } \\
\text { nomic value to } \\
\text { society } \\
\text { Development of } \\
\text { knowledge-based } \\
\text { economies }\end{array}$ & $\begin{array}{l}\text { Commitment to } \\
\text { creating economic } \\
\text { and social value } \\
\text { and impact } \\
\text { Improving the } \\
\text { economic welfare } \\
\text { As a driving force } \\
\text { for economic } \\
\text { growth }\end{array}$ & $\begin{array}{l}\text { Focused on ful- } \\
\text { filling teaching, } \\
\text { research and } \\
\text { entrepreneurial } \\
\text { activities simulta- } \\
\text { neously } \\
\text { The new university } \\
\text { missions are } \\
\text { focused on their } \\
\text { contribution to } \\
\text { social development } \\
\text { and economic } \\
\text { growth } \\
\text { Generate jobseek- } \\
\text { ers } \\
\text { Publishing papers } \\
\text { with practical } \\
\text { implications } \\
\text { Knowledge transfer } \\
\text { (patents, licenses, } \\
\text { spin-offs) }\end{array}$ & $\begin{array}{l}\text { Contribution to } \\
\text { national, regional } \\
\text { and local economic } \\
\text { and social } \\
\text { development } \\
\text { Social and econom- } \\
\text { ic utility } \\
\text { The emphasis is } \\
\text { upon 'economic } \\
\text { value' } \\
\text { Contributing to } \\
\text { local and regional } \\
\text { economic and } \\
\text { social development }\end{array}$ & $\begin{array}{l}\text { Involves exten- } \\
\text { sion from ideas } \\
\text { to practical } \\
\text { activity, capital- } \\
\text { izing } \\
\text { knowledge, } \\
\text { organizing new } \\
\text { entities and } \\
\text { managing risks } \\
\text { University's role } \\
\text { in economic and } \\
\text { social develop- } \\
\text { ment, based } \\
\text { upon innovation } \\
\text { Regional eco- } \\
\text { nomic develop- } \\
\text { ment }\end{array}$ & $\begin{array}{l}\text { Universities have a } \\
\text { strategic role to play } \\
\text { in regional, national, } \\
\text { and economic devel- } \\
\text { opment. } \\
\text { Providing economic } \\
\text { autonomy }\end{array}$ & $\begin{array}{l}\text { Contributing to the } \\
\text { technological and } \\
\text { economic develop- } \\
\text { ment } \\
\text { Contribution to } \\
\text { develop and sustain- } \\
\text { ing economic growth }\end{array}$ & $\begin{array}{l}\text { The core entrepre- } \\
\text { neurial university } \\
\text { missions (teaching, } \\
\text { research, and so-- } \\
\text { cio-economic } \\
\text { contribution) } \\
\text { Facilitating eco- } \\
\text { nomic growth } \\
\text { To stimulate } \\
\text { regional economic } \\
\text { development }\end{array}$ & 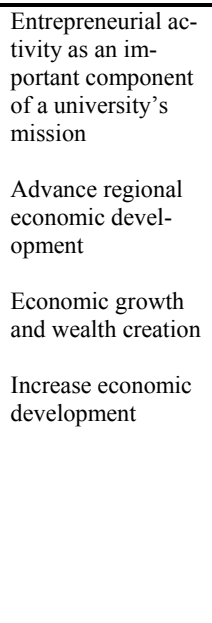 & $\begin{array}{l}\text { The mission of } \\
\text { universities has } \\
\text { evolved from } \\
\text { engaging in tradi- } \\
\text { tionally focused } \\
\text { activities such as } \\
\text { teaching and } \\
\text { research to a } \\
\text { broader remit that } \\
\text { includes commer- } \\
\text { cialization and } \\
\text { economic devel- } \\
\text { opment. } \\
\text { "Third mission" } \\
\text { university }\end{array}$ \\
\hline 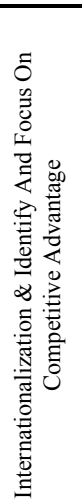 & $\begin{array}{l}\text { Efforts to recruit } \\
\text { graduate students } \\
\text { internationally }\end{array}$ & $\begin{array}{l}\text { Internationalization } \\
\\
\text { Attracts interna- } \\
\text { tional and entre- } \\
\text { preneurial staff } \\
\text { (including teach- } \\
\text { ing, research and } \\
\text { PhDs) } \\
\text { Demonstrates } \\
\text { internationalization } \\
\text { in its approach to } \\
\text { teaching }\end{array}$ & $\begin{array}{l}\text { Increasingly col- } \\
\text { laborating, net- } \\
\text { working and part- } \\
\text { nering with multi- } \\
\text { ple industries, } \\
\text { universities } \\
\text { As a driving force } \\
\text { for } \\
\text { competitiveness in } \\
\text { global markets }\end{array}$ & $\begin{array}{l}\text { Internationalization } \\
\text { processes; } \\
\text { International alum- } \\
\mathrm{ni} \\
\text { engagement } \\
\text { Creating an inter- } \\
\text { national presence } \\
\text { University's inter- } \\
\text { national reputation } \\
\text { is a vital stimulus } \\
\text { Increasing global } \\
\text { competition }\end{array}$ & & $\begin{array}{l}\text { Retain competitive } \\
\text { advantage accrued } \\
\text { and develop new } \\
\text { sources of competi- } \\
\text { tive advantage } \\
\text { within the service } \\
\text { sector }\end{array}$ & $\begin{array}{l}\text { The elimination of } \\
\text { barriers to interna- } \\
\text { tional collaborative } \\
\text { research created by } \\
\text { different } \\
\text { national laws regard- } \\
\text { ing the ownership } \\
\text { and exploitation of } \\
\text { IPRs }\end{array}$ & $\begin{array}{l}\text { The role of inter- } \\
\text { nationalization } \\
\text { has been misun- } \\
\text { derstood in the } \\
\text { academic debate } \\
\text { of emerging uni- } \\
\text { versities models } \\
\text { To innovation, } \\
\text { competiveness }\end{array}$ & Internationalization & 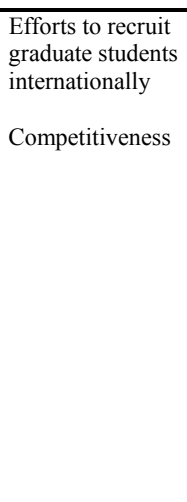 \\
\hline
\end{tabular}




\section{Entrepreneurial education}

In general, universities are expanding, developing and training their entrepreneurship to the Institute, including all employees and students, which shows the university require having an organizational structure to support entrepreneurship development as well as provide the appropriate tools for providing teaching and training opportunities from indoors and outdoors environments.

Entrepreneurial education is divided into two parts: the curriculum and the academic workforce empowerment:

\section{A) Curriculum}

The development and implementation of entrepreneurship courses for students, as one of the important factors helps in the further integration of the university into an entrepreneurial university (17). Therefore, reform of curriculum and efforts to attract international postgraduate students are a common answer to the call for increased entrepreneurship in universities (18).

Entrepreneurship courses for students and academics are effective and facilitating formal factors and entrepreneurial teaching methods are effective informal factors in the proposed conceptual framework of entrepreneurial universities. Also, the number of courses, programs, and entrepreneurial activities, the proposed period in entrepreneurship and the research methodology are the criteria for assessing the educational objectives of university entrepreneurship (19).

The goals of an entrepreneurial university are focused on the production of graduates who are not only job seeker but also job creator (20). Universities, in order to become entrepreneur, must apply the resources and capabilities to enable their students, faculty and staff in initiatives, business opportunities, and ideas transformation into products, through action-based curriculum and integrated with research (21).

\section{B) Empowering the academic workforce}

Creating skills and entrepreneurial abilities in faculty members and academics is one of the performance indicators in university entrepreneurship. The university is also investing in employee development to support entrepreneurship. Employees are a key source of strategy, entrepreneurship education, support for business start-ups and all entrepreneurial activities that the university wants to develop (8).

Although the formation of companies by the university is not a new phenomenon, universities have recently accepted to encourage their employees to do so. In addition, faculty members maintain their position who are involved in the formation of companies. Some universities are concerned that entrepreneurial interests may alienate faculty members from their traditional educational activities, and some academics avoid attending in universities that are under the control of companies that share research projects on campus. Companies that have been formed by academics have their impact on the university. In this case, universities will engage in commercialization of research (15).
Creation and presentation of applied knowledge

According to Kirby et al. (2011), one of the criteria for assessing the success of entrepreneurial universities is the transfer of knowledge (through patents, licenses, and contracts), which is the consequence of these universities in the research sector (19). Universities play an important role in the development of knowledge-based economies for the creation, application and dissemination of knowledge (22).

Universities must have mechanisms for exploiting knowledge and internal resources, and they have a great deal to exchange knowledge, through collaboration and participation. Knowledge exchange should be part of institutional politics. Therefore, the university should support the mechanisms of knowledge exchange and cooperation with the external environment. The university also conducts regular monitoring and evaluation of academic knowledge exchange activities (8).

One way that universities can add value in access to key strategic goals of a university is to improve knowledge exchange processes (23).

Facilitate and consolidate communications and interactions with other elements of the national innovation system

The University is committed to collaborating and sharing knowledge with industry, society and the public sector, and has strong connection with incubators and science parks in order to create opportunities for the dynamic exchange of knowledge. Universities can generate value added from their relationships with their outside environment. Hence, university communication with the industry is one of the official facilitators in the university entrepreneurship (19).

Building a close relationship with business and communities is a strategy for the development of entrepreneurial universities. Many successful international businesses have excellent communication links. Establishing strong relationships with business and industry is essential to ensure that education and research are directly related to society and the environment (23).

Triple Helix is a framework that interacts with college, industry and government to interact with each other in order to innovate in a knowledge-based society. The university discovers opportunities through government and industry communications, and it is provided by faculty, staff and students (21).

In the entrepreneurship ecosystem, universities have strong partnerships to create or support relationships and communications between entrepreneurs, risky investors, business incubators, and other actors (24).

\section{Development of entrepreneurship culture}

Promotion of entrepreneurship culture is one of the mechanisms that can help entrepreneurship in universities and is one of the criteria for the success of entrepreneurial universities. At the heart of every culture of entrepreneurship, entrepreneurial universities have the ability to innovate, recognize and create opportunities, teamwork, risk 
acceptance, and response to challenges. Understanding the culture of entrepreneurship by students leads to their favorable attitude toward entrepreneurship in the university (19).

Creating a culture of entrepreneurship in the staffing group is essential to increase and improve the quality of entrepreneurial activities of the university. The encouragement and appreciation of entrepreneurial behavior in all employees reinforces the commitment to development as an entrepreneurial university. Universities must also encourage employees and students to develop entrepreneurial mindsets, behaviors and skills through a range of mechanisms that can be devoted to the individual. Universities can create and reinforce a culture of entrepreneurship by hiring employees with strong entrepreneurial backgrounds. Therefore, the institution should use entrepreneurial attitudes and experience as a measure of employment (8).

The development of entrepreneurial culture is a business strategy, and strong leadership and good governance for the development of an entrepreneurial culture are vital and necessary (23). Hence, an entrepreneurial university must inject an entrepreneurial mentality into any graduate, and this is not possible without the content of entrepreneurship in the academic curriculum (25).

Governance and academic leadership in the direction of economic growth and development

Entrepreneurial universities have a new management ethics in governance, leadership and planning. In addition, university leaders need to be expert in identifying business opportunities that create from the dynamic engagement of organizations and their stakeholders (26).

Also, leadership and governance are as one of the dimensions of the Entrepreneurship Guidance Framework in Europe, stating that strong leadership and good governance are crucial to developing an entrepreneurial culture within an institution. In fact, entrepreneurship should be an important part of the strategy of universities (8). One of the main factors of entrepreneurial universities is the entrepreneurial attitude of academics, managers, researchers, employees and students. This means that a sufficient mix of leadership and university governance and a positive attitude toward entrepreneurship in the university community are causing significant changes in the university. As a result, an entrepreneurial university requires managers with leadership attributes in full time professional positions to carry out their mission (27).

But, implementation of entrepreneurial processes in universities is condition for entrepreneurship and one of which is an entrepreneurship management style for leadership development. The collaborative leadership is one of the leadership styles that is most effective at entrepreneurial universities (21).

One of the university's subordinate roles in governance and leadership is identifying and focusing on the competitive advantage of economic growth and development. Increasing university reputation, competition, and differentiation has been introduced as one of the activities that contribute to the potential of entrepreneurship to achieve key university goals (23). Internationalization is another subordinate role for universities in the functioning of governance and leadership, so having an international perspective at all levels (19), is one of the characteristics of these universities. Also, establishing an international university presence can help in reviewing the potential of entrepreneurship in achieving key university strategic goals of value added (23).

Reviewing and managing the multiple missions of the university to boost economic growth is a necessary requirement for $3^{\text {rd }} \mathrm{GU}$. In such organizations, in addition to traditional teaching and research missions, social and economic values are added to society (7).

The mission of universities has evolved from participating in more focused activities, such as teaching and research to a broader stage, including commercialization and economic development. In addition, universities have a strategic role in regional, national and economic development. In this context, the Triple Helix model plays a role (28).

\section{Discussion}

All authors who have yet discussed the necessity of conversion for universities to third-generation universities, introduced $3^{\text {rd }} \mathrm{GU}$ as entrepreneurship universities, and presented the corresponding functions for these universities. But our findings in this study, while criticizing this approach as an incomplete one in existing literature, introduced $3^{\text {rd }} \mathrm{GU}$ as entrepreneurial and innovative universities (as Kyro and Matila mentioned) (2) and, while extracting, elaborating and synthesizing the functions of the $3^{\text {rd }} \mathrm{GU}$ in this format, Finally, a comprehensive and applied model for $3^{\text {rd }} \mathrm{GU}$ was abstracted and resulted.

This model improves the weakness of the lack of a functional model in the texts by providing an useful guide for moving universities toward the $3^{\text {rd }} \mathrm{GU}$.

Based on the findings of this study, researchers categorize the functions of universities and provide it in the following model (Fig. 2):

\section{Innovative and entrepreneurial activities}

Innovative and entrepreneurial activities are the foundation of all other functions. Each research starts with a basic research based on the community's needs and must pass through the translational research field before use. The work of translational research is an intervention proposal and requires a deep understanding of basic research and existing problems. In the discussion of thirdgeneration universities, translational research seems to be very important because it is innovation proposal before the impact of innovation is evaluated.

When it comes to its impact, we need to look at how to present it in the form of goods or services, which is done in the research and development unit. Valorization is an event or action that occurs in this unit. In the next step, the production and marketing of a product or service is considered. These sequences of activities guided us to innovative and entrepreneurial activities (first core functions of $3^{\text {rd }} \mathrm{GU}$ ). 


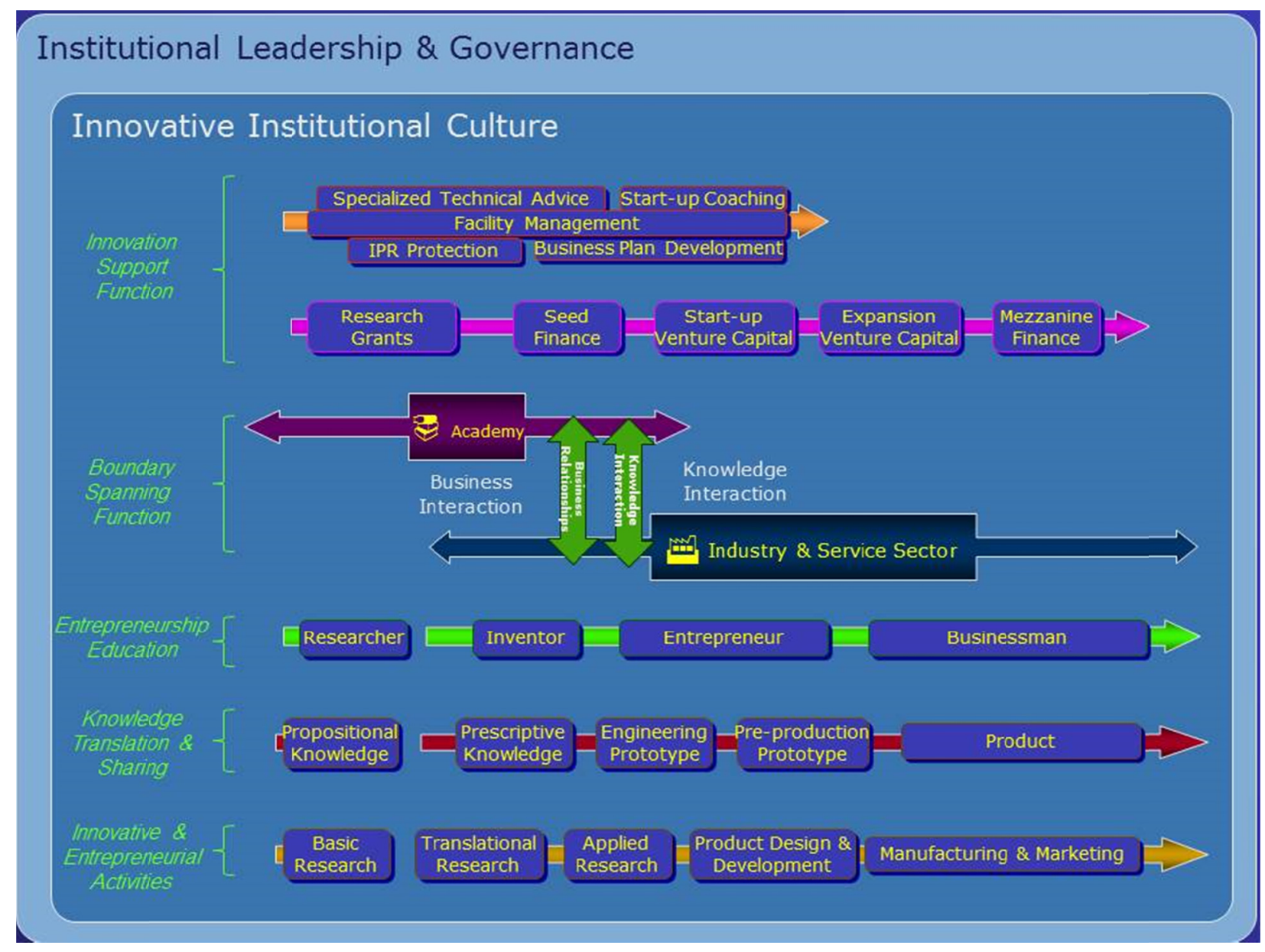

Fig. 2. Core Innovation Functions Model of $3^{\text {rd }} \mathrm{GU}$

\section{Sharing and translating knowledge}

In this section, we translate and share the knowledge produced (propositional and prescriptive knowledge). Then, knowledge transformed to engineering prototype and, pre-production prototype and finally product. In other words, the $3^{\text {rd }} \mathrm{GU}$ is a university that runs the path of management and knowledge sharing from academia to business. Here is the creation of knowledge related to innovation and entrepreneurial activities and the provision of knowledge related to the exchange, transfer, diffusion and management of knowledge (29). These conversations led to sharing and translating knowledge activities (second core functions of $3^{\text {rd }} \mathrm{GU}$ ).

\section{Entrepreneurial education}

Entrepreneurial education is also related to the curriculum and entrepreneurship education, as well as the empowerment of staff and faculty members. At $3^{\text {rd }} \mathrm{GU}$, we expect that the faculty member is not just an educator, but also a researcher, inventor, entrepreneur, and businessman, and their empowerment programs should be provided (30). These arguments directed us to entrepreneurial education (third core functions of $3^{\text {rd }} \mathrm{GU}$ ).

\section{Boundary Spanning Function}

The $3^{\text {rd }}$ GU must go beyond boundaries and interact with the industry and government sectors in accordance with the Triple Helix model (31). These interactions can be discussed both in knowledge and in business background:

Levels of knowledge interactions include strategy and planning, information transfer, transfer of skills between sectors through individuals, increase skills, increase exploiting commercial knowledge, and level of access to facilities and capabilities.

Levels of business interactions, including: collaboration and Business partnerships, contracts and consultations, business partnerships, businesis competition, business associations, business networks, graduate associations, university-industry affiliate organizations, business growth centers and science and technology parks (32).

These activities conducted us to boundary spanning function (forth core functions of $3^{\text {rd }} \mathrm{GU}$ ).

\section{Support activities (financial and non-financial)}

The University's financial support activities include research grants, start- up venture capital, expansion venture capital, Seed Finance and Mezzanine Finance.,

The University's non-financial supports include special-

Med J Islam Repub Iran. 2021 (8 Mar); 35.32. 
ized technical advice, start-up coaching, facility management and intellectual property protection and business plan development. These setting of activities guide us to Support activities (financial and non-financial) (fifth core functions of $\left.3^{\text {rd }} \mathrm{GU}\right)$.

\section{Develop innovative and entrepreneurial culture}

The development of the innovative institution culture is accompanied by activities such as changing the mentality and the perspective of the academic workforce by providing entrepreneurship courses, which is a clear reflection of entrepreneurship in the organization's symbols and slogans. Also, rewarding to entrepreneurial activities and promoting entrepreneurial activities in social \& cultural events are the functions of the $3^{\text {rd }} \mathrm{GU}$ in develop innovative and entrepreneurial culture.

\section{Institutional governance and leadership in the di- rection of economic growth and development}

Leaders in these universities, in order to support entrepreneurial and innovative activities, balance management behavior practices with transformative leadership styles (33). All functions take place in the context of institutional culture and institutional leadership style, and this style of leadership is that makes the institution's culture. All these functions together move the university towards economic and social value added (7).

\section{Conclusion}

Universities are required to survive and stay in the cycle of the innovation system and the Triple Helix model to promote their functions. Moving toward $3^{\text {rd }} \mathrm{GU}$, that is both innovative and entrepreneurial, can contribute to these changes. Therefore, awareness of the functions of these types of universities is needed both for their survival and for the development of the economies of the states. In this study, various functions of the $3^{\text {rd }} \mathrm{GU}$ were identified and determined, which included 7 main functions of innovative and entrepreneurial activities, supportive activities (financial and non-financial), entrepreneurial education (curriculum and academic workforce empowerment), creation and the provision of applied knowledge, Boundary Spanning Function or communications and interactions with other elements of the national innovation system (state and industry), the development of innovative and entrepreneurial culture and institutional governance and leadership in the direction of economic growth and development.

The proposed model in this study can be the basis for the planning, implementation and evaluation processes of universities in updating their functions in the transition to $3^{\text {rd }}$ GU. Obviously future studies can use these functions and design tools and relevant questionnaires to determine the rate of success in each university and provide the necessary suggestions to provide the mechanism for the establishment of a successful university.

\section{Acknowledgements}

This article was conducted as part of the first author's doctoral thesis which was supported by IUMS (Code no.
IR. IUMS. FMD.REC1396.9221486203).

Conflict of Interests

The authors declare that they have no competing interests.

\section{References}

1. Wissema JG. Towards the third generation university: Managing the university in transition: Edward Elgar Publishing; 2009.

2. Kyrö P, Mattila J, editors. Towards future university by integrating Entrepreneurial and the 3rd Generation University concepts. 17th Nordic Conference on Small Business Research Helsinki, Finland; 2012.

3. Skribans V, Lektauers A, Merkuryev Y. Third generation university strategic planning model development. Munich Personal RePEc Archive (MPRA). 2013, https://mpra.ub.uni-muenchen.de/49168

4. Grant MJ, Booth A. A typology of reviews: an analysis of 14 review types and associated methodologies. Health Info Libr J. 2009;26(2):91-108

5. Baycan T. Knowledge commercialization and valorization in regional economic development: Edward Elgar Publishing; 2013.

6. Gianiodis PT, Markman GD, Panagopoulos A. Entrepreneurial universities and overt opportunism. Small Bus Econ. 2016;47(3):60931

7. Guerrero M, Urbano D, Fayolle A, Klofsten M, Mian S. Entrepreneurial universities: emerging models in the new social and economic landscape. Small Bus Econ. 2016;47(3):551-63.

8. Ec-Oecd A. Guiding Framework for Entrepreneurial Universities. European Commission. 2012:1-54.

9. Grandi A, Grimaldi R. Academics' organizational characteristics and the generation of successful business ideas. J Bus Ventur. 2005;20(6):821-45.

10. Link AN, Scott JT. Opening the ivory tower's door: An analysis of the determinants of the formation of US university spin-off companies. Res Pol. 2005;34(7):1106-12.

11. Audretsch DB. From the entrepreneurial university to the university for the entrepreneurial society. J Technol Transf. 2014;39(3):313-21.

12. Gibb A, Hannon P. Towards the entrepreneurial university. IJEE 2006;4(1):73-110.

13. Kotha R, George G, Srikanth K. Bridging the mutual knowledge gap: Coordination and the commercialization of university science. AMJ. 2013;56(2):498-524.

14. Baldini N, Fini R, Grimaldi R. The Transition toward Entrepreneurial Universities. The Chicago handbook of university technology transfer and academic entrepreneurship (Chapter Eight). 2015 Mar 9;218

15. Etzkowitz H. Anatomy of the entrepreneurial university. SSI 2013;52(3):486-511.

16. O'Shea RP, Chugh H, Allen TJ. Determinants and consequences of university spinoff activity: a conceptual framework. J Technol Transf. 2008;33(6):653-66.

17. Witte J. The introduction of two-tiered study structures in the context of the Bologna process: A theoretical framework for an international comparative study of change in higher education systems. High Educ Policy. 2004;17(4):405-25.

18. Mok KH. Fostering entrepreneurship: Changing role of government and higher education governance in Hong Kong. Res Pol 2005;34(4):537-54.

19. Kirby DA, Guerrero M, Urbano D. Making universities more entrepreneurial: Development of a model. CJAS. 2011;28(3):302-16.

20. Schulte P. The entrepreneurial university: a strategy for institutional development. High Educ Eur. 2004;29(2):187-91.

21. Savetpanuvong P, Pankasem P, editors. Entrepreneurial University model: A theoretical perspectives on strategy, entrepreneurship, and innovation. Management of Innovation and Technology (ICMIT), 2014 IEEE International Conference on; 2014: IEEE.

22. Laukkanen M. Exploring alternative approaches in high-level entrepreneurship education: creating micromechanisms for endogenous regional growth. Entrepreneur Region Develop. 2000;12(1):25-47.

23. Coyle P, Gibb A, Haskins G. The Entrepreneurial University: from concept to action. NCEE. 2013:2-58.

24. Mason C, Brown R. Entrepreneurial ecosystems and growth oriented entrepreneurship. Final report to OECD, Paris. 2014;30(1):77-102.

25. Thorp H, Goldstein B. The entrepreneurial university. Inside Higher 
Ed. 2010 Sep 27.

26. Darling J, Gabrielsson M, Seristö H. Enhancing contemporary entrepreneurship: a focus on management leadership. CEBR. 2007;19(1):4-22.

27. Sporn B. Management. Building adaptive universities: Emerging organisational forms based on experiences of European and US universities TEAM. 2001;7(2):121-34.

28. Harrington D, Walsh A. Evolving Nature and Structures of Entrepreneurial Universities. The World Scientific Reference On Entrepreneurship: Volume 1: Entrepreneurial Universities Technology and Knowledge Transfer: World Scientific; 2017. p. 85-110.

29. Trigwell K, Martin E, Benjamin J, Prosser M. Scholarship of teaching: A model. HERD. 2000;19(2):155-68.

30. Lackéus M. Entrepreneurship in education: What, why, when, how. Background paper. 2015.

31. Etzkowitz H, Zhou C. The triple helix: University-industrygovernment innovation and entrepreneurship: Routledge; 2017.

32. Howard JH, Matthews M. Mapping the Nature and Extent of Business-University Interaction in Australia. Canberra: Australian Research Council; 2001.

33. Alferoff C, Knights D. Making and mending your nets: managing relevance, participation and uncertainty in academic-practitioner knowledge networks. BJM. 2009;20(1):125-42. 